\title{
Формування механізму управління прибутком комерційних підприсмств
}

\begin{abstract}
Прибуток є однією з основних економічних категорій, щзо відображає всі сторони та аспекти діяльності суб' єктів господарювання $і$ забезпечує їх стабільне функціонування. Отримання прибутку і його максимізація дає підприємству можливість постійного розвитку та вдосконалення, забезпечуючи його конкурентними перевагами на ринку. Досягнення максимальної величини прибутку i відповідно мінімізація збитку-одна $з$ основних иілей будь-якого комерчійного підприємства. Метою статті є розкриття теоретичних основ економічного механізму управління прибутком на основі використання прочесів його планування, аналізу $i$ розподілу. Виявлено, щуо в структуру механізму управління прибутком входить: державне нормативно-правове і ринкове економічне регулювання прочесу формування і використання прибутку, а також система конкретних внутрішніх методів і прийомів, які формує підприємство. Підкреслено, що теоретичні основи управління прибутком повинні базуватись на принципах інтеграції із загальною системою управління, задля комплексного вирішення поставлених завдань, гнучкості, варіативності підходів до розробки управлінських рімень. Обтрунтовано, щзо в процесі формування прибутку підприємства часто стикаються із зменшенням фактичного виторгу в порівнянні з планом. Це слід виправляти за рахунок зниження витрат $i$ забезпечення позареалізаційних надходжень. Доведено, щзо основною метою процесу розподілу прибутку є оптимізація пропориій між часткою прибутку, яка капіталізується $і$ яка спрямовується на споживання. Оптимізація необхідна для забезпечення реалізаиї стратегії розвитку підприємства й зростання його ринкової вартості. Підтверджено необхідність створення на підприємствах спеціальних окремих підрозділів - иентрів прибутку, які забезпечують в динаміці оптимальне поєднання величин об'єму продажу, реалізаційних иүін, змінних $i$ постійних витрат, доходів та чистого прибутку.
\end{abstract}

Ключові слова: прибуток, аналіз прибутку, механізм прибутку, управління прибутком, фінансові результати.

DOI: https://doi.org/10.33146/2307-9878-2019-2(84)-154-158

M.L. HONCHARENKO

(Kharkiv State Academy of Culture, Kharkiv, Ukraine)

\section{Formation of a Profit Management Mechanism for Commercial Enterprises}

Profit is one of the main economic categories, reflecting all aspects of the activities of business entities and ensures their stable operation. Making and maximizing a profit gives the company the opportunity for continuous development and improvement, providing it with competitive advantages in the market. Achieving maximum profit and minimizing costs is one of the main goals of any commercial enterprise. The purpose of the article is to reveal the theoretical foundations of the economic mechanism of profit management based on the use of the processes of its planning, analysis and distribution. As study results shows the structure of the mechanism of profit management includes: state regulatory and market economic regulation of the process of formation and use of profit, as well as a system of specific internal methods and techniques that form the enterprise. It was emphasized that the theoretical foundations of profit management should be based on the principles of integration with the general management system, for the solution of the different tasks, flexibility and variability of approaches to the development of management decisions. It was substantiated that in the process of forming profits, enterprises often face a decrease in actual revenues compared with the plan. This situation should be corrected by reducing costs and ensuring nonoperating income. It was proved that the main goal of the profit distribution process is to optimize the proportions

\footnotetext{
* Гончаренко Маргарита Леонідівна, доцент кафедри менеджменту і адміністрування Харківської державної академії культури (м. Харків), кандидат економічних наук, доцент.
} 
between the share of profits, its capitalization and consumption. Optimization is necessary to ensure the implementation of the enterprise development strategy and the growth of its market value. The necessity of creating special separate subdivisions at enterprises (profit centers), which provide in dynamics the optimal combination of the values of sales volume, selling prices, variable and fixed costs, income and net profit, was confirmed.

Keywords: profit, profit analysis, profit mechanism, profit management, financial results.

Постановка проблеми. Ефективне управління фінансовими результатами діяльності підприємства передбачає створення організаційно-економічних систем забезпечення цього управління, опанування основних прийомів формування прибутку, використання сучасних методів його планування й аналізу. На даному етапі розвитку більшість підприємств i організацій практично не мають комплексних теоретичних розробок, які обгрунтовують формування механізму управління прибутком підприємства та дозволяють здійснювати ефективне управління його фінансовою діяльністю.

Аналіз останніх досліджень і публікацій. Основне коло питань, пов'язаних $з$ управлінням процесом формування і розподілу прибутку в процесі операційної, інвестиційної та комерційної діяльності підприємства розглядалось в роботах багатьох українських авторів, серед яких І.О. Бланк [1], I.C. Лапіна, О.М. Гончаренко [2], О.А. Зінченко [3]. Вагомий внесок у розвиток теорії управління прибутком та іiі практичного використання зробили економісти ближнього зарубіжжя. Так, А.Н. Асаул i М.Г. Квициния [4] стверджують, що оптимізація управління прибутком, як i витратами-це обов'язкова функція контролінгу. Управління прибутком в контексті інтересів різних користувачів міститься в дослідженнях В.В. Ковальова [5]. В роботі Н.А. Масилевича [6] розглядаються особливості управління процесами формування i розподілу прибутку 3 аналізом різних факторів впливу на ці процеси. Проте конкретизація основних складових механізму забезпечення прибутковості підприємства та пошуки напрямів їх удосконалення потребують подальших досліджень.

Метою статті $\epsilon$ розкриття та поглиблення теоретичних основ економічного механізму управління прибутком на основі використання процесів його планування, аналізу і розподілу.

Виклад основного матеріалу дослідження. Прибуток будь-якого підприємства $є$ для нього внутрішнім джерелом розвитку, а його розмір безпосередньо залежить від рівня організації фінансового менеджменту, який базується на достовірній оцінці можливостей здійснення комерційної діяльності суб'єкта господарювання та розрахунку iї ступеню ризику. Від цього безпосередньо залежить ефективність господарювання підприємства, захист капіталу від «розшарування», зменшення витрат в процесі його операційної та інших видів діяльності.

За словниковим визначенням, «прибуток-це перевищення доходів від продажу товарів та послуг над витратами на виробництво і продаж цих товарів; один 3 найважливіших показників фінансових результатів господарської діяльності підприємства» [7, c. 247].

Під механізмом управління прибутком розуміють систему основних елементів, які регулюють процес розробки і реалізації управлінських рішень в галузі його формування, розподілу й використання [1, с. 35]. В структуру даного механізму входять наступні елементи:

- державне нормативно-правове регулювання процесу формування і використання прибутку;

- ринковий механізм формування й використання прибутку підприємства;

- внутрішній механізм регулювання окремих аспектів управління прибутком;

- система конкретних методів i прийомів здійснення управління формуванням і використанням прибутку.

Державне правове регулювання насамперед передбачає врахування багатьох важливих моментів у господарюванні: відрахування податків, регулювання механізму амортизації активів, облік розміру відчислень прибутку в резервний фонд i т. ін. Ринковий механізм формування й використання прибутку враховується при обгрунтуванні цін на продукцію; він також надає інформацію про вартість кредитів для підприємств, дохідність деяких цінних паперів, можливу дохідність капіталу, що демонструє зростання ролі цього механізму сумісно з розвитком ринкових відносин в державі. Внутрішній же механізм управління прибутком формує саме підприємство, регламентуючи ті чи інші управлінські рішення в рамках обраної цільової політики управління прибутком.

Управління прибутком на рівні підприємства передбачає використання системного підходу як провідного в теорії менеджменту організацій. Такий підхід передбачає дослідження способів організації підсистем у єдине ціле й вплив процесів функціонування системи в цілому на іï окремі ділянки (рис. 1).

Перед кожним із зображених на рис. 1 блоків стоять власні завдання, але їх реалізація спрямована на досягнення загальних спільних цілей суб'єкта господарювання, а саме:

- максимізацію чистого прибутку i ринкової вартості підприємства;

- підтримання конкурентоспроможності на ринку в довгостроковому періоді;

- забезпечення ліквідності та платоспроможності підприємства;

- підтримку прийнятного рівня самофінансування;

- забезпечення інвестиційної привабливості підприємства [2]. 


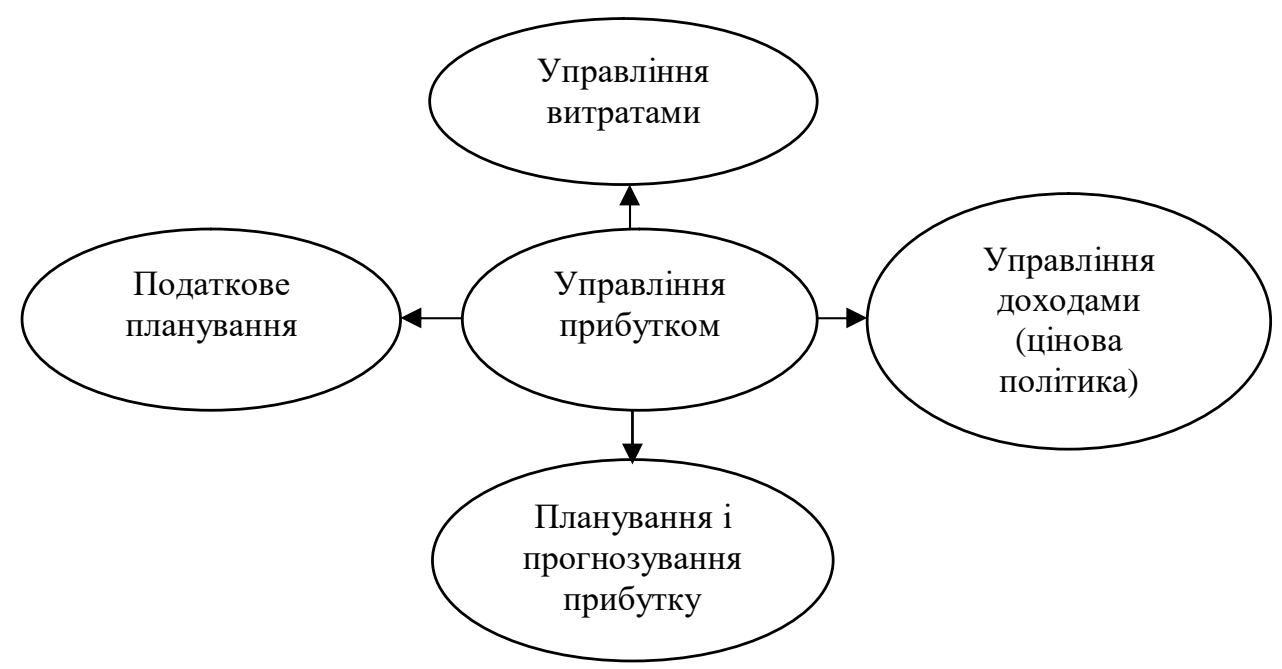

Рис. 1. Основні підсистеми моделі управління прибутком

Джерело: побудовано на основі [1].

Таким чином, механізм управління прибутком являє собою комплекс скоординованих методів, інструментів та важелів, які забезпечують збалансованість фінансово-господарських відносин у сфері планування, формування і розподілу прибутку в процесі адаптації підприємства до факторів змін зовнішнього середовища при забезпеченні більшменш стабільного внутрішнього середовища. Тому кожне підприємство повинне орієнтуватися на деякі загальні теоретичні основи управління прибутком, які представлено в табл. 1.

Теоретичні основи управління прибутком підприсмства

Таблиияя 1

\begin{tabular}{|c|c|}
\hline Параметр & Характеристика \\
\hline Ціль & $\begin{array}{l}\text { Підтримка ефективності фінансово-господарчої діяльності підприємства і виявлення } \\
\text { додаткових джерел ії підвищення. }\end{array}$ \\
\hline Об’єкт & Фінансові відносини в сфері формування, розподілу і використання прибутку. \\
\hline Суб'єкт & Фактори зовнішньої та внутрішньої середи підприємства. \\
\hline Принципи & $\begin{array}{l}\text { Інтеграція із системою управління. } \\
\text { Комплексний характер вирішення поставлених завдань. } \\
\text { Високий динамізм управління (постійні зміни умов зовнішнього й внутрішнього } \\
\text { середовища, які вимагають швидкої адаптації до цих змін; спрацювання багатьох видів } \\
\text { ризику). } \\
\text { Варіативність підходів до розробки управлінських рішень. } \\
\text { Формування цілей управління прибутком з урахуванням пріоритетів розвитку } \\
\text { господарської діяльності. }\end{array}$ \\
\hline $\begin{array}{l}\text { Механізм } \\
\text { реалізації }\end{array}$ & $\begin{array}{l}\text { Розробка гнучкої фінансової політики. } \\
\text { Прогнозування й планування прибутку. } \\
\text { Формування систем управління витратами. } \\
\text { Оптимізація програм і напрямків реалізації продукції (послуг). }\end{array}$ \\
\hline Інструментарій & $\begin{array}{l}\text { CVP-аналіз. } \\
\text { Операційний і фінансовий леверидж. } \\
\text { Система показників рентабельності. }\end{array}$ \\
\hline
\end{tabular}

Джерело: систематизовано автором на основі опрацьованих джерел.

Як видно 3 табл. 1, механізм управління прибутком реалізується через сукупність методів і торкається різних направлень професійних знань, таких, як фінансове планування й регулювання, фінансовий облік i аудит, фінансовий аналіз й менеджмент. Оптимальною ж $є$ «розробка організаційно-економічного механізму, що включає в себе конкретні методики та інструкції щодо його впровадження, а також забезпечення чіткої реалізації менеджментом підприємств його функцій [3, с. 8].
Управління процесом формування прибутку завжди починається із планування фінансових надходжень в розрахунковому періоді. Воно здійснюється фінансовими службами підприємства на основі аналізу розрахункових потреб (як суми витрат) у фінансових ресурсах для забезпечення процесу виробничої й комерційної діяльності за всіма напрямками господарювання. Враховуються фактично можливі завантаження виробничих потужностей для виконання сформованого портфелю 
замовлень, а також результати маркетингових досліджень, що дозволяють прогнозувати появу нових замовлень протягом планового періоду. Деякі сучасні автори рекомендують виділяти групи продукції, що приносять найбільший прибуток, погрупово постійно проводити аналіз ціни і об'єму продукції, що реалізується, для визначення найбільш розумного компромісу, який допоможе комерційним підприємствам, не дивлячись на зниження об'ємів продажу, збільшити надходження додаткових грошових коштів за рахунок збільшення ціни, торгових націнок або направлень реалізації [8]. Однак, підкреслюючи можливість використання впливу фактора ціноутворення на зростання прибутку в сучасних умовах, слід зазначити, що вповільнення інфляційних процесів, насичення ринку товарами, розвиток конкуренції значно обмежують можливості виробників підвищувати ціни та отримувати прибуток за допомогою цього фактора. В результаті найбільш актуальним серед внутрішніх факторів впливу на прибуток стає фактор зниження витрат.

При плануванні процесу формування прибутку підприємства необхідно особливу увагу приділяти наступним моментам:

а) у сучасних умовах господарської діяльності винятково висока ймовірність зменшення фактичного виторгу від реалізації внаслідок скорочення виробничого навантаження в порівнянні 3 його плановою величиною, що робить актуальним планування додаткових (резервних) джерел фінансових ресурсів, насамперед, позареалізаційних надходжень;

б) для істотного розширення фінансових можливостей підприємства необхідна коректна (тобто не суперечна чинному фіскальному законодавству) мінімізація планованих платежів по податку на прибуток та іншим податкам.

Отже, планування прибутку - базова складова частина механізму управління i фінансового планування. Об'єктом планування є елементи операційного прибутку, у першу чергу, прибутку від реалізації продукції. Він визначається на базі планованого обсягу продажу (планованого виторгу), відповідно до якого коригується виробнича програма й повна собівартість продукції.

Деякі автори [4; 5] стверджують необхідність створення центрів прибутку, ціль яких - управління процесом планування й отримання максимального прибутку шляхом оптимального поєднання визначних елементів: об'єму продажу, реалізаційних цін, змінних і постійних витрат. Це фактично самостійні підрозділи, в яких приймаються рішення щодо доходів і витрат, кількості споживаних ресурсів і можливого рівня доходів. Менеджери таких центрів можуть нести відповідальність також за досягнення окремих нефінансових показників, наприклад, ступеню задоволення потреб споживачів, підвищення «гудвілу» підприємства та інших.

На формування прибутку чинять вплив особи, які мають пряме або посереднє відношення до господарюючого суб'єкту. Для цих осіб «мають неоднакове значення показники прибутку як індикатори успішності роботи підприємства, обгрунтованості участі в ній капіталу і доцільності встановлення 3 нею контрагентських відносин» [5, c. 510]. Всі господарські відносини формуються у тріаді «власник-держава - менеджмент», що відображується у трьох варіантах розрахунку прибутку: фінансовому, податковому й управлінському. Тобто, окремі розраховані показники прибутку аналізуються окремими користувачами i мають пріоритетне значення для різних суб'єктів фінансових відносин.

При формуванні механізму управління прибутком велике значення має процес розподілу, в якому приймають участь: держава, власники підприємства й саме підприємство. Пропорції цього розподілу значною мірою впливають на ефективність діяльності підприємства як позитивно, так і негативно. Багато різних факторів спрацьовує саме при розподілі прибутку між власниками підприємства i самим підприємством.

У період технічного переозброєння й модернізації виробництва, освоєння нових видів продукції, підприємство вкрай потребує фінансових ресурсів, які, в першу чергу, повинні надати власники. Вони одержують наявний дохід на вкладений капітал та той дохід, який може знаходитись в режимі «відкладеного очікування». Тобто власники зможуть одержати свої дивіденди після виходу виробництва на заплановану потужність виробництва й об'єм реалізації.

На підприємстві розподілу підлягає прибуток після сплати податків і виплати дивідендів. Розподіл цієї частини прибутку відбиває процес формування цільових фінансових фондів і резервів підприємства.

Цільові фонди, сформовані із чистого прибутку, є важливим компонентом його фінансової системи. Вони призначаються для фінансування виробничотехнічного, соціального, наукового й іншого розвитку, а також вирішення інших завдань поточного або перспективного характеру. Керівництво підприємства має право (безпосередньо або за рішенням власника) самостійно визначати склад, розміри, порядок формування й використання засобів цих фондів.

Підприємства зазвичай створюють фонд нагромадження, кошти з якого використовуються на фінансування витрат виробництва, на науководослідні, проектні роботи, розробку й освоєння нових видів продукції, технічне переобладнання і реконструкцію, погашення довгострокових позичень, фінансування приросту обігових коштів. Фонд споживання в основному слугує для фінансування соціального розвитку й соціальних потреб. Кошти 3 резервного фонду спрямовуються на покриття збитків, погашення боргів по внескам в статутний фонд, погашення облігацій акціонерного товариства або викуп акцій у випадку відсутності інших коштів [6, с. 134-135].

3 підвищенням нестабільності зовнішнього середовища відрахування в резервний фонд повинні 
носити першочерговий характер Це засвідчує готовність комерційного підприємства до страхування всіх видів ризику, пов'язаного 3 підприємницькою діяльністю.

Висновки. Прибуток $є$ однією 3 основних економічних категорій, що відображає відносини, які склались в процесі виробництва й реалізації. Він синтезує всі сторони та аспекти діяльності суб' єктів господарювання і забезпечує іх стабільне функціонування. Тому будь-яке підприємство повинне застосовувати системний підхід до управління прибутком, який передбачає дослідження засобів організації різних підсистем господарюючого суб' єкту в єдине ціле, а також впливу процесів функціонування системи в цілому на іï окремі ділянки.

Під механізмом управління прибутком слід розуміти систему елементів, а також взаємозв' язків та відносин, що виникають в процесі реалізації управлінських рішень щодо його формування, розподілу й використання. Планування і аналіз будьякого економічного показника, в тому числі прибутку, вимагає знання факторів, що впливають на його рівень i динаміку. Ефективне управління прибутком передбачає не тільки керування його динамікою, але й розподілом, що припускає наявність обгрунтованих методичних підходів до вирішення цього завдання. Підприємство будь-якої форми власності, маючи фінансову самостійність і незалежність, має право вирішувати, на які цілі й у яких розмірах спрямовувати прибуток, що залишився після сплати податків у бюджет й інших обов'язкових платежів. Основною ж метою політики розподілу прибутку $є$ оптимізація пропорцій між часткою, яка капіталізується i часткою, яка спрямовується на споживання. У зв'язку з цим, кожне підприємство має сформувати ефективний механізм управління прибутком 3 урахуванням забезпеченості реалізації стратегії розвитку підприємства i зростання його ринкової вартості. Стратегія управління прибутком повинна розглядатись як невід'ємна складова частина загальної стратегії економічного розвитку підприємства.

\section{4 Список використаних джерел}

1. Бланк И. А. Управление прибылью. 3-е изд., перераб. и доп. К.: Ника-Центр, 2007. 768 с.

2. Лапіна I. C., Гончаренко О.М.Фінансовий менеджмент: навч. посіб. Одеса: Атлант, 2016. 313 с.
3. Зінченко О. А. Удосконалення підходів до формування механізму управління фінансовими результатами підприємства. Збірник наук. праць Черкаського державного технологічного університету. Сер. Економічні науки. 2012. Вип. 32(2). С. 8-10.

4. Асаул А. Н., Квициния М. Г. Управление затратами и контроллинг. Сухуми, 2013. 290 с.

5. Ковалев В. В. Финансовый менеджмент. Теория и практика. Москва: ТК Велби, Проспект, 2007. $1024 \mathrm{c}$.

6. Масилевич Н. А. Финансовый менеджмент. Минск: БГТУ, 2006. 336 с.

7. Завадський Й. С., Осовська Т. В., Юшкевич О. О. Економічний словник. К.: Кондор, 2006. 356 с.

8. Безугла Ю. Є. Сценарії розвитку економічної діяльності підприємств. Актуальні проблеми економіки. 2015. № 8(170). С. 402-408.

\section{References}

1. Blank, I. A. (2007). Upravlenie priblyu [Profit management] ( $3^{\text {th }}$ edition). Kyiv: Nika-Centr.

2. Lapina, I. S., Honcharenko, O. M. (2016). Finansovyi menedgment [Financial Management]. Odesa: Atlant.

3. Zinchenko, O. A. (2012). Udoskonalennia pidhodiv do formuvannya mehanismu upravlinnya finansovymy rezultatamy pidpriyemstva [Improvement of approaches to the formation of a mechanism for managing the financial results of the enterprise]. Zbirnik naukovyh prats Cherkasskogo derzhavnogo universytetu. Ekonomichny nauky, 32(2), 8-10.

4. Asaul, A. N., Kvitsiniya M. H. (2013). Upravlenie zatratamy i controlling [Cost management and controlling]. Sukhumi.

5. Kovalyov, V. V. (2007). Finansovyi menedgment. Teoriya i praktika [Financial management. Theory and practice]. Moskva: Prospekt.

6. Masylevich, N. A. (2006). Finansovyi menedgment [Financial management]. Minsk: BGTU.

7. Zavadskiy, J. S., Osovskya, T. V., Yushkevich, O. O. (2006). Ekonomichnyi slovnik [Economic dictionary]. Kyiv: Kondor.

8. Bezugla, Yu. E. (2015). Stsenarii rozvitku ekonomichnoi diyalnosti pidpriyemstv [Scenarios for the development of economic activity of enterprises]. Aktualni problemy ekonomiky, 8(170), 402-408. 